\title{
The Native Oyster Restoration Alliance (NORA) and the Berlin Oyster Recommendation: bringing back a key ecosystem engineer by developing and supporting best practice in Europe
}

\author{
Bernadette Pogoda $^{1, *}$, Janet Brown ${ }^{2}$, Boze Hancock ${ }^{3}$, Joanne Preston ${ }^{4}$, Stephane Pouvreau ${ }^{5}$, \\ Pauline Kamermans ${ }^{6}$, William Sanderson ${ }^{7,8}$ and Henning von Nordheim ${ }^{9}$ \\ ${ }^{1}$ Alfred-Wegener-Institute Helmholtz Centre for Polar and Marine Research, Am Handelshafen12, 27570 Bremerhaven, Germany \\ 2 Association of Scottish Shellfish Growers (ASSG), Stirling FK8 2BN, UK \\ 3 The Nature Conservancy, C/O URI Graduate School of Oceanography, 215 South Ferry Rd., Narragansett, RI 02882, USA \\ ${ }^{4}$ Institute of Marine Sciences, University of Portsmouth, Portsmouth PO4 9LY, UK \\ 5 Ifremer, Univ Brest, CNRS, IRD, LEMAR, 29840 Argenton en Landunvez, France \\ ${ }^{6}$ Wageningen Marine Research, Wageningen University and Research, PO Box 77, 4400 AB Yerseke, The Netherlands \\ ${ }^{7}$ Centre for Marine Biodiversity \& Biotechnology, EGIS, Heriot-Watt University, Edinburgh, UK \\ ${ }^{8}$ St Abbs Marine Station, St Abbs, Scottish Borders, UK \\ ${ }^{9}$ Federal Agency for Nature Conservation, Directorate Marine Nature Conservation, Isle of Vilm, 18581 Putbus, Germany
}

Received 30 January 2019 / Accepted 14 May 2019

Handling Editor: Ellen Kenchington

\begin{abstract}
Efforts to restore the native oyster Ostrea edulis and its associated habitats are gaining momentum across Europe. Several projects are currently running or being planned. To maximize the success of these, it is crucial to draw on existing knowledge and experience in order to design, plan and implement restoration activities in a sustainable and constructive approach. For the development of best practice recommendations and to promote multidimensional knowledge and technology exchange, the Native Oyster Restoration Alliance (NORA) was formed by partners from science, technology, nature conservation, consultancies, commercial producers and policy-makers. The NORA network will enhance scientific and practical progress in flat oyster restoration, such as in project planning and permitting, seed oyster production, disease management and monitoring. It also focuses on joint funding opportunities and the potential development of national and international regulatory frameworks. The main motivation behind NORA is to facilitate the restoration of native oyster habitat within its historic biogeographic range in the North Sea and other European seas along with the associated ecosystem services; services such as enhancing biodiversity, including enhanced fish stocks, nutrient cycling and sediment stabilization. NORA members agreed on a set of joint recommendations and strongly advise that any restoration measure should respect and apply these recommendations: The Berlin Oyster Recommendation is presented here. It will help guide the development of the field by developing and applying best practice accordingly. NORA also aims to combine the outreach activities of local projects for improved community support and awareness and to provide educational material to increase knowledge of the key ecological role of this species and increase awareness among regulators, permit providers and stakeholders. A synthesis of $O$. edulis restoration efforts in Europe is provided and underlines the general significance in the field.
\end{abstract}

Keywords: Ostrea edulis / Berlin Oyster Recommendation / biogenic reef / ecosystem service / biodiversity

\section{Introduction}

The native European Oyster Ostrea edulis once covered vast areas of the open North Sea and other European coastal waters. As an ecosystem engineer it built biogenic reefs and

*Corresponding author: bernadette.pogoda@awi.de played a key ecological role for the wider ecosystem by providing many essential ecosystem services. $O$. edulis is a sublittoral species and was abundant up to $50 \mathrm{~m}$ depth (Kerckhof et al., 2018; Pogoda, 2019). Oysters have been heavily fished as a valuable resource over centuries. During the era of industrialization and the introduction of powered dredging technologies, oyster habitat was fished 
down to functional extinction in most European regions (Berghahn and Ruth, 2005; Lotze, 2005; Lotze et al., 2005; Thurstan et al., 2013; Duchêne et al., 2015). In many areas oyster fisheries were abandoned as catches were no longer profitable. But bottom trawling for other target species remains a barrier to regenerating structured habitat such as oyster beds or reefs because shellfish habitats are vulnerable to physical impact (Cook et al., 2013). In many European regions, remaining and managed oyster beds, contributing to commercial production, have been severely affected by diseases (e.g. Marteilia, Bonamia) in the 1920s and the 1970s/ 1980 s, which resulted in elevated mortalities (Arzul et al., 2006; Pogoda, 2019). Together with human induced stressors, the absence of broodstock and substrate impedes natural recovery of native oyster populations. Today, natural oyster beds and reefs have vanished or are in a degraded state, with limited ecological function, throughout Europe (Thurstan et al., 2013). This status was reached before the end of the 19th century and consequently, there is a shifted baseline (Pauly, 1995; Alleway and Connell, 2015; Pogoda, 2019) leading to a debate about the extent to which native oysters formed reefs. The current perception of oyster habitat vastly underestimates its historical and ecological significance. Historical fishing reports document "living crusts of shellfish" or "clumps of oysters in the dredges" or "oysters are so often found in clusters on the natural beds instead of singly" (Möbius, 1877; Fulton, 1896; Korringa, 1946). Current experimental research shows that Ostrea edulis is capable of forming biogenic reef structures through shell accretions (Christianen et al., 2018; Merk et al., 2019) and underlines the ecological importance of oysters as biogenic habitat builders. Nature conservation goals need to acknowledge the historical extent and importance of oyster habitat and the role restoration of oyster habitat can play for biodiversity, for the increased production of many fish species and for improving water quality (zu Ermgassen, 2016; Hancock and zu Ermgassen, 2018).

In Europe, habitat restoration as a marine natureconservation measure and obligation of the EU Habitats Directive (European Parliament, 1992, 2008) and the OsloParis Commission (OSPAR recommendation OSPAR, 2010), is a relatively new practice. Some skepticism still exists regarding the risk of negative impacts on the ecosystem in the case of mismanagement or failures. The alternative course, of protection or passive restoration ("allow nature to do the work") may be supported as a better option (Prach, 2016). However, we argue that for native oysters, breeding is only possible when densities are sufficiently high, in which case protection or passive restoration would suffice. Where the native oyster is either absent or present in very low densities, or shell substrates have been totally removed, active restoration becomes a necessity for the return of native flat oyster reefs. Therefore, restoration trials have to be planned, implemented and communicated carefully, incorporating the benefit of the experience gained from examples in other areas of the world, especially from USA and Australia. For the relatively new field of restoring native flat oyster reefs in Europe, the development of best practice and decision-making tools is of fundamental importance (Metzger et al., 2017). Against this background, partners from science, technology, nature conservation, consultancies, commercial producers and policy-makers founded the Native Oyster Restoration Alliance (NORA) and developed the initial Berlin Oyster Recommendation, which is presented here:

\section{BERLIN OYSTER RECOMMENDATION - Bringing back an ecological key-player: principles for native oyster restoration in Europe}

\subsection{Preface}

Oyster habitats are hot-spots of biodiversity and are vital to the health of the surrounding ecosystem but are among the most threatened marine habitats worldwide (Beck et al., 2011). Oyster reefs and beds are biogenic structures formed by oysters that occur at high densities and provide the dominant structural component and significant vertical relief on otherwise unstructured sea-floor (Reise, 2005; OSPAR, 2009). As an ecological keystone-species it offers substrate, spawning ground, food and shelter for many more species (Smyth and Roberts, 2010). Their ecological role can be compared to the function of coral reefs in tropical regions. In Europe, native oysters once formed extensive beds and reefs along North Atlantic coastlines and in the North Sea, even in offshore regions of moderate depth (Olsen, 1883; Gercken and Schmidt, 2014). However, over $90 \%$ of former oyster reefs have been lost (Lotze, 2005; Beck et al., 2011).

Over the past two decades, substantial headway has been made in progressing restoration of oyster habitats in the USA. While restoration efforts historically sought to address declines in oyster landings, many recent efforts focus on recovering the valuable and diverse ecosystem services these oyster habitats provide (Luckenbach et al., 2005; Hancock et al., 2006; Peabody and Griffin, 2008). Across Europe, native oyster restoration is also starting to gain momentum. The Oslo-ParisCommission (OSPAR) included Ostrea edulis on the list of threatened and declining species and habitats, for which restoration measures should be developed and the EU Habitats Directive also calls for the protection, conservation and restoration of biogenic reefs in European waters (OSPAR, 2008). Over the last 3-5 years, several projects have started with the aim of recovering the biodiversity and the ecosystem services provided by oysters (Laing et al., 2005; Shelmerdine and Leslie, 2009; Woolmer et al., 2011; Gravestock et al., 2014; Smaal et al., 2015; Harding et al., 2016).

High fishing pressure and poor shell management practices not only resulted in the decline of living oysters, but also in the loss of the most important natural settlement substrate for oyster larvae: oyster shells (Korringa, 1941; Laing et al., 2005; Airoldi and Beck, 2007). In waters with sufficient larval abundances, the lack of suitable substrate can be the limiting factor for the recovery of oyster populations (Smaal et al., 2015). Throughout much of Europe, a lack of broodstock (adult breeding individuals) in sufficiently high density for successful breeding may also be the reason for low larval abundances. Furthermore, in many European ecoregions the invasive protozoan parasite Bonamia ostreae is present today and able to increase mortality in native oysters (van Banning, 1991; Cáceres-Martínez et al., 1995; Arzul 
et al., 2006; Culloty and Mulcahy, 2007; Abollo et al., 2008; Laing et al., 2014). Bonamia-monitoring will be an important tool for the selection of eventually tolerant populations.

Against this background the Marine Directorate of the German Federal Agency for Nature Conservation and the Alfred-Wegener-Institute Helmholtz Centre for Polar and Marine research organised a Kick-off Workshop in Berlin "Native oyster restoration in Europe - current activities and future perspectives" with the idea of exploring interest in the foundation of a European Network for Native Oyster Restoration.

The workshop was attended by 65 participants from 11 countries, representing experts from science, nature conservation, commercial production, bio-consulting and policy advisers. It became obvious that despite the existing momentum and will for restoring native oysters and their valuable ecosystem services, several barriers to the successful wide scale uptake of native oyster restoration still needed to be addressed. Addressing these barriers requires the combined focus of a "network" of restoration practitioners as well as academics and managers who recognise the environmental benefits to be gained from restoring this once dominant habitat. Thus, a European "Native Oyster Restoration Alliance" was conceived as an ideal mechanism to accelerate the impact of restoring native oyster habitats in Europe.

The participants of the workshop discussed a number of pertinent issues related to native oyster restoration and protection while:

- considering that oysters have historically played a critical role both ecologically and economically in marine environments worldwide;

- noting that globally wild and native shellfish populations including those throughout Europe - are largely degraded, and their ecosystem service value is similarly reduced;

- accepting that conditions in many areas are different now from when oysters were abundant 100-200 years ago;

- confirming that successful oyster restoration projects have been implemented around the globe on various scales;

- realising that native oyster restoration in Europe should be promoted and facilitated by defined cooperative actions;

- believing that restoration should be integrated into conservation policy, marine spatial planning and marine development;

- agreeing that participants and key institutions will work together towards the recovery of native oyster habitat and the associated services on an ecosystem scale.

Following these discussions workshop participants established the Native Oyster Restoration Alliance (NORA) for the protection and restoration of the endangered European oyster.

The undersigned workshop participants (which represented the core group of the European expertise on the subject) formulated a series of specific recommendations. These recommendations are addressed to national, international, intergovernmental agencies, as well as regulators, scientists, NGOs and potential investors of the respective countries and urges them to strongly support these recommendations with the aim to provide a healthy and resilient ecosystem in the North East Atlantic and the North Sea.

\subsection{Recommendations}

Participants and members of the Native Oyster Restoration Alliance (NORA) agreed on the following recommendations:

1. Produce sufficient oysters for restoration of oyster reefs Background: Sufficient seed oyster supply is a key limiting factor for native oyster restoration projects in Europe. Translocation between sites of seed oysters or any other size classes from wild beds should be discouraged to avoid increasing the pressure on still existing wild beds and reduce the risk of spreading invasive species and disease. Recommendation: Action should be undertaken to support existing hatcheries, spatting ponds and spat collector techniques and to establish new hatcheries and spatting ponds for the production of robust and genetically diverse Ostrea edulis seed. Broodstock sanctuaries should be established and used for local reinforcements.

2. Identify and create suitable sites for restoration of oyster reefs

Background: Restoration projects to recover Ostrea edulis habitat will only succeed in areas where environmental conditions are suitable and no bottom disturbance, e.g. bottom trawl fishery, occurs.

Recommendation: Sufficient undisturbed and suitable areas should be identified for the restoration and protection of Ostrea edulis in all regions of its indigenous range. This includes the restoration of suitable substrate in some areas. It will be important to identify and afford protection to several major sites in Europe, where:

- Ostrea edulis was recorded previously but has disappeared ("reintroduction" sites)

- Ostrea edulis is still present, but in very low density ("reinforcement" sites)

- Ostrea edulis is abundant with sufficient reproduction and settlement for the habitat to persist in the long term ("conservation" sites)

3. Provide suitable substrate for successful recruitment Background: Sustainable success of restoration efforts depends on successful recruitment and, therefore, not only on the supply of sufficient larvae but also on the availability of suitable substrate. After their planktonic phase, oyster larvae prefer to settle on oyster shells. Suitable and abundant settlement substrate is a major limiting factor for Ostrea edulis recovery in areas with natural spatfall and of high importance for sustainable restoration.

Recommendation: Extraction of Ostrea edulis shells from the marine environment for other usages should be stopped. The addition of suitable substrate will ease recruitment of larvae.

4. Respect Bonamia-free areas

Background: In many European ecoregions, the invasive parasite Bonamia is present today. Bonamia ostreae is an invasive protozoan parasite infecting haemocytes of native oysters and inducing physiological disorders, potentially resulting in the eventual death of the animal. High mortality rates have been described for cultivation sites with high densities of oysters and elevated summer temperatures. Despite this, tolerant populations appear to exist in France, The Netherlands, Spain and Ireland. Genetic studies have demonstrated that tolerance to this 
parasite is heritable and genomic studies have identified QTLs and expressed genes associated with tolerance.

Recommendation: Research to better understand the biology of the Bonamia parasite and infection dynamics should be encouraged. Biosecurity protocols must be strictly followed in Bonamia-free areas. Any area where there is functional extinction of Ostrea edulis should be treated as a Bonamia-free area. Techniques should be sought to take advantage of any disease tolerance that has developed in broodstock from high disease load areas, without transferring pathogens.

5. Create common monitoring protocols

Background: Native oyster restoration is in its infancy in Europe. There are numerous outstanding questions regarding best practice for restoration of the European native oyster. A shared monitoring protocol will allow lessons and outcomes to be shared between all European restoration efforts. This will reduce duplication of effort and ensure that progress towards successful restoration is as rapid as possible.

Recommendation: Monitoring protocols that will provide comparable results for projects throughout Europe and for restored sites should be developed and followed. Where possible, monitoring should include the assessment of ecosystem services on a habitat and ecosystem scale.

6. Preserve genetic diversity

Background: The preservation of the genetic diversity of European native oyster populations is of central importance for maintaining its ability to adapt to changing environmental conditions, stress factors (disease, climate change) and to facilitate the long-term survival of native oyster habitats in Europe.

Recommendation: Established hatchery and pond production protocols should be adapted to preserve the extant genetic diversity of native oysters in Europe.

The full list of contributors to the Berlin Oyster Recommendation is available at noraeurope.eu.

\section{Current European pilot restoration initiatives}

Ostrea edulis survived in coastal and estuarine areas in several European countries, mainly due to management of oyster beds within commercial farming. These managed populations, as well as hatchery produced seed oysters, provide important starting populations for restoration attempts, to be undertaken in areas where any bottom disturbance (such as bottom trawling fishery) is excluded, e.g. Marine Protected Areas. Currently, pilot projects for native oyster restoration are being carried out in UK, France, the Netherlands and Germany.

In England, two restoration projects have been established in locations that historically supported large oyster populations. On the south coast, the Solent Oyster Restoration Project (SORP) was established after catastrophic declines in stock densities and the collapse of a fishery (Gravestock et al., 2014; Harding et al., 2016). It aims to reseed the Solent with oysters, and restore oyster bed habitat to support a self-sustaining population. Since 2017, broodstock oysters are suspended in novel restoration cages from marina pontoons across the Solent to increase reproduction and provide a source of larvae to populate the surrounding seabed. Monitoring of growth, health, survival, reproduction and recruitment is ongoing. In addition, seabed cages containing native oysters were deployed to test their physiological performance and ecosystem service provision at different elevations above the seabed. Effects of density on survival, growth, reproduction, benthic structure and biodiversity are assessed estuary-wide to provide data for future seabed deployment within designated European and UK marine sites. On the east coast, The Essex Native Oyster Restoration Initiative (ENORI) was established in 2011 as a collaboration between oyster fishermen, nature conservation organisations, academia and government regulators. It is restoring selfsustaining populations of native oysters within a Marine Conservation Zone across the Blackwater, Roach, Crouch and Colne estuaries. Broodstock oysters and substrate (shell material) were deployed to the seabed to increase reproduction and recruitment of a nationally important breeding population. ENORI has created an adaptive management fisheries plan to recover native oyster populations which may allow a sustainable fishery.

In Wales, a feasibility study and baseline surveys identified the need for native oyster restoration (Woolmer et al., 2011). In 2019, the Wales Native Oyster Restoration Project has been established by Natural Resources Wales. It will focus on a series of restoration plots and will address fundamental sitespecific questions relating to survival, recruitment, density effects, and the impacts of Bonamia disease and non-native species. Associated habitat and biodiversity enhancement will also be assessed.

In Scotland, oyster restoration feasibility studies started in the late 1990s and have recently gained momentum (Shelmerdine and Leslie, 2009; Fariñas-Franco et al., 2018). Oysters have been extirpated for over one hundred years in many sites (Thurstan et al., 2013; Fariñas-Franco et al., 2018). In 2013 the Dornoch Environmental Enhancement Project (DEEP) was initiated. After a feasibility study (Fariñas-Franco et al., 2018), Scottish oysters were successfully translocated to the Dornoch Firth in 2017. Monitoring of growth, health, survival, reproduction and recruitment is ongoing (Sanderson, in prep.). Supporting research projects have been established to examine the contribution oysters make to blue carbon storage as well as the behaviour and therefore likely destinations of oyster larvae from the restoration sites (Rodriguez-Perez et al., 2019). Furthermore, substrate (shell material) was deployed to the seabed to increase recruitment by creating a series of "reefs" and "beds". These habitats are being populated with oysters, grown by suppliers from across Scotland. Additional restoration projects are planned in Plockton, Ardfern and Loch Ryan.

In France, the flat oyster was once a dominant species in coastal waters, but is now confined to only a few localized environments. Since 2018, the Flat Oyster Recovery project (FOREVER) promotes the reestablishment of native oysters in Brittany (France). It will provide a regional inventory of the main native oyster beds and a detailed analysis of the ecology and dynamics of the still remaining beds in the Bays of Brest and Quiberon. General functional status will be 
Table 1. Recommendations as listed in the Berlin Oyster Recommendation on the Future of Native Oyster Restoration in Europe. These are based on agreements of participants of the first meeting of the Native Oyster Restoration Alliance (NORA) in Berlin 2017, NORA members and on a literature review focusing on restoration of Ostrea edulis.

\begin{tabular}{ll}
\hline Recommendation & Actions \\
\hline $\begin{array}{l}\text { 1. Produce sufficient oysters } \\
\text { for restoration of oyster reefs }\end{array}$ & Support existing hatcheries \\
& Support spatting ponds \\
& Support spat collector techniques
\end{tabular}

Establish broodstock sanctuaries

2. Identify and create suitable sites Reintroduction sites for restoration of oyster reefs / Site selection

\section{Provide suitable substrate for successful recruitment}

\section{Respect Bonamia-free areas}

\section{Create common monitoring protocols}

\section{Preserve genetic diversity}

Reinforcement sites

\section{Conservation sites}

Extraction of shells from the marine environment for other usages should be stopped

Addition of suitable substrate to ease recruitment of larvae

Research should be encouraged to better understand the Bonamia parasite and infections

Biosecurity protocols must be strictly followed

Take advantage of any disease tolerance that has developed in broodstock Develop and follow monitoring protocols

Include the assessment of ecosystem services on a habitat and ecosystem scale

Preserve the extant genetic diversity of native oysters in Europe
Scientific reference

(Vercaemer et al., 2004; Pogoda, 2019;

Colsoul et al., 2019)

(Culloty et al., 2004; Ashton and Brown, 2009; Syvret and Woolmer, 2015; Colsoul et al., 2019)

(Kamermans et al., 2004; Bataller et al., 2006;

Lok and Acarli, 2006; Burke et al., 2008;

van den Brink, 2012; Rodriguez-Perez et al., 2019;

Colsoul et al., 2019)

(Brumbaugh et al., 2006; Colsoul et al., 2019)

(Clewell et al., 2000; Laing, 2005;

Laing et al., 2005; Ashton and Brown, 2009;

Shelmerdine and Leslie, 2009;

Woolmer et al., 2011; Keenelyside et al., 2012;

Gravestock et al., 2014; Fariñas-Franco et al., 2018;

Pogoda, 2019)

(Kennedy and Roberts, 1999; Laing, 2005;

Laing et al., 2005; Roberts et al., 2005;

Kennedy and Roberts, 2006; Woolmer et al., 2011;

Gravestock et al., 2014; Helmer et al., 2019)

(University Marine Biological Station Millport, 2007)

(Laing, 2005; Laing et al., 2005;

Airoldi and Beck, 2007)

(University Marine Biological Station Millport, 2007) Artificial Reefs: (Baine, 2001; Brumbaugh et al., 2006; Ashton and Brown, 2009)

(Culloty and Mulcahy, 2001; Culloty and Mulcahy, 2007; Carrasco et al., 2012)

(Laing, 2005; Laing et al., 2005; Cranford et al., 2012; Brenner et al., 2014; Syvret and Woolmer, 2015)

(Naciri-Graven et al., 1998; Culloty et al., 2001, 2004; Culloty and Mulcahy, 2001)

(Laing, 2005; Laing et al., 2005; Brumbaugh et al., 2006)

(Leewis et al., 1997; Brumbaugh et al., 2006;

Coen et al., 2007; Grabowski and Peterson, 2007;

Ashton and Brown, 2009; Gercken and Schmidt, 2014;

Christianen et al., 2018)

(Saavedra, 1997; Vercaemer et al., 2003; Laing, 2005;

Laing et al., 2005; Sobolewska and Beaumont, 2005;

University Marine Biological Station Millport, 2007;

Ashton and Brown, 2009; Lallias et al., 2010) evaluated by density, size structure, mortality, health and genetic status, as well as by a better understanding of the recruitment dynamics within an oyster bed (larval abundance, larval behaviour, settlement processes). Associated benthic diversity and trophic interactions will also be assessed. Restoration and management measures will be implemented in partnership with local stakeholders (fisheries and shellfish farming bodies, regional government authorities, environmental management organizations, e.g. Natura 2000).
The development of substrate structures is an important goal to increase recruitment.

In the Netherlands, oyster restoration studies started in 2014. A feasibility study, initiated by the Dutch government, identified potential locations and requirements for restoration, e.g. environmental conditions for survival, growth, reproduction and recruitment (Smaal et al., 2015, 2017; Kamermans et al., 2018a, 2018b). Since 2016, the Voordelta restoration project aims at enlarging an existing nearshore bed of 


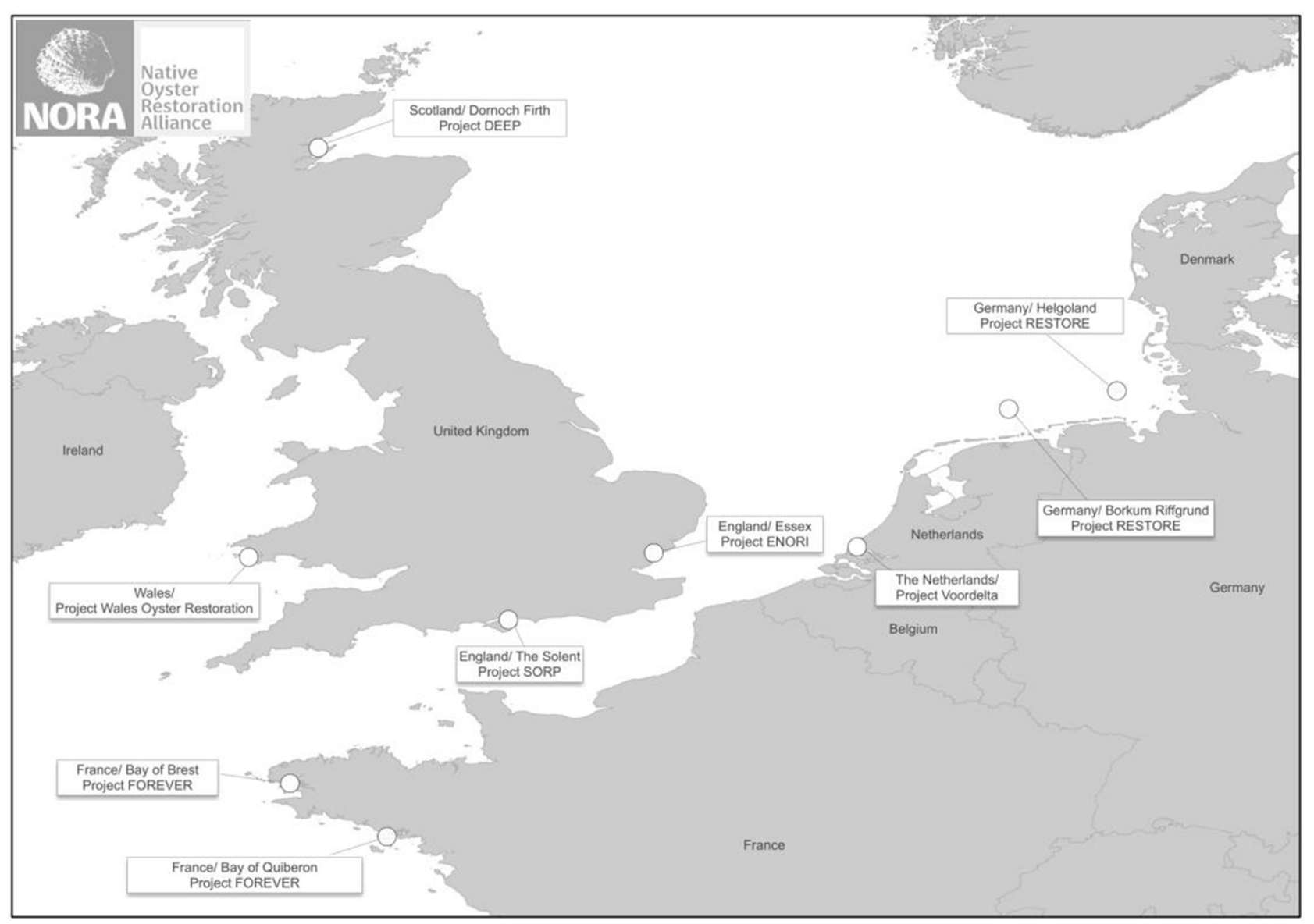

Fig. 1. Map of the North Sea and adjacent European seas (GCS_WGS_1984). It shows European countries contributing to the Native Oyster Restoration Alliance and currently planning or implementing restoration pilot projects or nature conservation measures with Ostrea edulis.

European oyster (O. edulis) and Pacific oyster (Crassostrea gigas) by translocation of Dutch broodstock oysters and by introduction of substrate (shell material) to increase reproduction and recruitment (Sas et al., 2016, 2018). Monitoring of growth, health, survival, reproduction and recruitment is ongoing. Associated benthic diversity was also assessed (Christianen et al., 2018; Sas et al., 2018). In 2018, restoration experiments were started at offshore sites (e.g. Borkum Reef Ground). Monitoring of growth, health, survival, reproduction and recruitment is ongoing.

As the $O$. edulis population in Lake Grevelingen is infected with Bonamia ostreae (Engelsma et al., 2010) and spreading of the disease should be avoided (Pogoda and von Nordheim, 2019), these oysters can only be used in the nearby Voordelta area (Kamermans et al., 2018c). Recently, O. edulis was rediscovered in the Dutch Wadden Sea (van der Have et al., 2018). At present, it is unknown if these oysters are disease free. Ongoing efforts to supply oysters for Dutch restoration projects focus on local spat collection and hatchery production of disease free, and at the same time disease tolerant, spat.

In the German Bight, the European oyster is believed to be functionally extinct since the 1950s. A feasibility study (Gercken and Schmidt, 2014) and further restoration projects were initiated by the German Federal Agency for Nature conservation (BfN). Since 2016, the testing and development project RESTORE aims at the sustainable restoration of the European oyster Ostrea edulis in the German North Sea. Two experimental sites are located within the historical distribution around the Island of Helgoland. Monitoring of growth, health, survival, reproduction and recruitment is ongoing. Field experiments with juvenile oysters show excellent growth and condition (Pogoda, 2019; Merk et al., 2019). Furthermore, adequate restoration sites have been identified and will be established in the Marine Protected Area and Natura 2000 site Borkum Riffgrund in 2019. Associated benthic diversity and trophic interactions will also be assessed. Sufficient supply of healthy and certified seed oysters was defined as a critical limiting factor for long-term restoration. The project PROCEED addresses biological and technological research questions to establish a healthy broodstock and a sufficient seed oyster production for native oyster restoration. Furthermore, it focuses on knowledge transfer and it will raise and improve a general awareness for this former native species and the importance of its restoration. The native oyster is characterized as an ecological key-player and oyster reefs are used as an example to explain biodiversity as a stabilizing factor for the wider ecosystem and to underline the general significance of ecosystem services. 


\section{Outlook}

The Native Oyster Restoration Alliance (NORA) is timely, and with its commitment and agreed "Berlin Oyster Recommendation" it is positioned to provide a solid basis for supporting European countries to implement commitments under the Habitats Directive, the Marine Strategy Framework Directive and OSPAR recommendations. NORA was initiated and supported by BfN and AWI who have now established an online presence at noraeurope.eu. Maintaining this communication, triggering relevant meetings and helping to advance the topics critical to developing oyster habitat restoration in European Seas will be essential activities of NORA. Similarly, maintaining communication with other shellfish restoration networks worldwide where valuable lessons can be learnt.

One important task of NORA is to implement the recommendations in coordination with the alliance members as a significant undertaking involving administrative, political and conservation or commercial aspects in the context of the various national jurisdictions. NORA subgroups will address issues such as site selection, monitoring and disease management. Their essential work will be instrumental for generating best practice at national levels in marine conservation and for ensuring that progress and developments are supported. NORA will facilitate marine habitat restoration and help to expand understanding and awareness of the ecological importance of oyster habitats.

Acknowledgements. We thank the funding institutions, ARK Natuurontwikkeling, Blue Marine Foundation, European Maritime Fund, German Federal Program for Biological Diversity, FEAMP Aquaculture Innovation, Marine Conservation Society, Marine Directorate of the German Federal Agency for Nature Conservation and Natural Resources Wales, for the substantial support of oyster restoration projects. We also acknowledge our industry project partners CochetEnvironnement, CRC Bretagne, ESITC-Caen, Glenmorangie, MDL Marinas, WindMW. Furthermore, we would like to thank the members of the Native Oyster Restoration Alliance (NORA) for their valuable contributions to the Berlin Oyster Recommendation and for sharing their knowledge and thoughts. Two anonymous reviewers helped to improve the manuscript; we thank them for their constructive criticism and helpful comments.

\section{References}

Abollo E, Ramilo A, Casas SM, Comesaña P, Cao A, Carballal MJ, Villalba A. 2008. First detection of the protozoan parasite Bonamia exitiosa (Haplosporidia) infecting flat oyster Ostrea edulis grown in European waters. Aquaculture 274: 201-207.

Airoldi L, Beck MW. 2007. Loss, status and trends for coastal marine habitats of Europe. Oceanogr Mar Biol Ann Rev 45: 357-405.

Alleway HK, Connell SD. 2015. Loss of an ecological baseline through the eradication of oyster reefs from coastal ecosystems and human memory. Conserv Biol 29: 795-804.

Arzul I, Miossec L, Blanchet E, Garcia C, Francois C, Joly JP. 2006. Bonamia ostreae and Ostrea edulis: A Stable Host-Parasite System in France? in 11th International Symposium on Veterinary Epidemiology and Economics, Cairns, Queensland, Australia.
Ashton EC, Brown JH. 2009. Review of technical requirements, approaches and regulatory framework for the restoration of native oysters in Scotland. pp. 43.

Baine M. 2001. Artificial reefs: a review of their design, application, management and performance. Ocean Coast Manag 44: 241-259.

Bataller E, Burke K, Ouellette M, Maillet MJ. 2006. Evaluation of spawning period and spat collection of the northernmost population of European oysters (Ostrea edulis L.) on the Canadian Atlantic coast. Department of Fisheries and Oceans, 2630, Canada, pp. 34.

Beck MW, Brumbaugh RD, Airoldi L, Carranza A, Coen LD, Crawford C, Defeo O, Edgar GJ, Hancock B, Kay MC, Lenihan HS, Luckenbach MW, Toropova CL, Zhang G, Guo X. 2011. Oyster reefs at risk and recommendations for conservation, restoration, and management. Bioscience 61: 107-116.

Berghahn R, Ruth M. 2005. The disappearance of oysters from the Wadden Sea: a cautionary tale for no-take zones. Aquat Conserv 15: 91-104.

Brenner M, Fraser D, Van Nieuwenhove K, O’Beirn F, Buck BH, Mazurie J, Thorarinsdottir G, Dolmer P, Sanchez-Mata A, Strand O, Flimlin G, Miossec L, Kamermans P. 2014. Bivalve aquaculture transfers in Atlantic Europe. Part B: Environmental impacts of transfer activities. Ocean Coast Manag 89: 139-146.

Brumbaugh RD, Beck MW, Coen LD, Craig L, Hicks P. 2006. A Practitioners' guide to the design and monitoring of shellfish restoration projects: an ecosystem services approach. The Nature Conservancy (NOAA), Arlington, MRD Educational Report No. 22, pp. 28.

Burke K, Bataller É, Miron G. 2008. Spat collection of a non-native bivalve species (European oyster, Ostrea edulis) off the eastern Canadian coast. J Shellfish Res 27: 345-353.

Cáceres-Martínez J, Robledo JAF, Figueras A. 1995. Presence of Bonamia and its relation to age, growth rates and gonadal development of the flat oyster, Ostrea edulis, in the Ría de Vigo, Galicia (NW Spain). Aquaculture 130: 15-23.

Carrasco N, Villalba A, Andree KB, Engelsma MY, Lacuesta B, Ramilo A, Gairín I, Furones MD. 2012. Bonamia exitiosa (Haplosporidia) observed infecting the European flat oyster Ostrea edulis cultured on the Spanish Mediterranean coast. $J$ Invertebr Pathol 110: 307-313.

Christianen MJA, Lengkeek W, Bergsma JH, Coolen JWP, Didderen K, Dorenbosch M, Driessen FMF, Kamermans P, ReuchlinHugenholtz E, Sas H, Smaal A, van den Wijngaard KA, van der Have TM. 2018. Return of the native facilitated by the invasive? Population composition, substrate preferences and epibenthic species richness of a recently discovered shellfish reef with native European flat oysters (Ostrea edulis) in the North Sea Mar Biol Res 14: 590-597.

Clewell A, Rieger J, Munro J. 2000. Guidelines for developing and managing ecological restoration projects. pp. 11.

Coen LD, Brumbaugh RD, Bushek D, Grizzle R, Luckenbach MW, Posey MH, Powers SP, Tolley SG. 2007. Ecosystem services related to oyster restoration. Mar Ecol Prog Ser 341: 303-307.

Colsoul B, Boudry P, Pérez-Parallé ML, Bratoš Cetinić A, Merk V, Pogoda B. 2019. Supply of European flat oyster (Ostrea edulis Linnaeus, 1758) seed: a review and prospects of production technologies, in preparation.

Cook R, Fariñas-Franco JM, Gell FR, Holt RHF, Holt T, Lindenbaum C, Porter JS, Seed R, Skates LR, Stringell TB, Sanderson WG. 2013. The substantial first impact of bottom fishing on rare biodiversity hotspots: a dilemma for evidence-based conservation. PLOS ONE 8: e69904. 
Cranford PJ, Kamermans P, Krause G, Mazurié J, Buck BH, Dolmer P, Fraser D, Van Nieuwenhove K, Francis X, Sanchez-Mata A. 2012. An ecosystem-based approach and management framework for the integrated evaluation of bivalve aquaculture impacts. Aquacult Environ Interac 2: 193-213.

Culloty SC, Cronin MA, Mulcahy MF. 2001. An investigation into the relative resistance of Irish flat oysters Ostrea edulis L. to the parasite Bonamia ostreae (Pichot et al., 1980). Aquaculture 199: 229-244.

Culloty SC, Cronin MA, Mulcahy MF. 2004. Potential resistance of a number of populations of the oyster Ostrea edulis to the parasite Bonamia ostreae. Aquaculture 237: 41-58.

Culloty SC, Mulcahy MF. 2001. Living with bonamiasis: Irish research since 1987. Hydrobiologica 465: 181-186.

Culloty SC, Mulcahy MF. 2007. Bonamia ostreae in the native oyster Ostrea edulis - a review. Mar Environ Health Ser 29: 1-36.

Duchêne J, Bernard I, Pouvreau S. 2015. Vers un retour de l'huître indigène en rade de Brest. Espèces 16: 51-57.

Engelsma MY, Kerkhoff S, Roozenburg I, Haenen OL, Van Gool A, Sistermans W, Wijnhoven S, Hummel H. 2010. Epidemiology of Bonamia ostreae infecting European flat oysters Ostrea edulis from Lake Grevelingen, The Netherlands. Mar Ecol Prog Ser 409: 131-142.

European Parliament. 1992. Council Directive 92/43/EEC of 21 May 1992 on the conservation of natural habitats and of wild fauna and flora. pp. 43 (47-50).

European Parliament. 2008. Directive 2008/56/EC of the European Parliament and of the Council of 17 June 2008 establishing a framework for community action in the field of marine environmental policy (Marine Strategy Framework Directive). pp. 21 (19-40).

Fariñas-Franco JM, Pearce B, Mair JM, Harries DB, MacPherson RC, Porter JS, Reimer PJ, Sanderson WG. 2018. Missing native oyster (Ostrea edulis L.) beds in a European Marine Protected Area: Should there be widespread restorative management? Biol Conserv 221: 293-311.

Fulton TW. 1896. The past and present condition of the oyster beds in the Firth of Forth. pp. 49 (244-293).

Gercken J, Schmidt A. 2014. Current status of the European oyster (Ostrea edulis) and possibilities for restoration in the German North Sea. pp. 88.

Grabowski JH, Peterson CH. 2007. Restoring oyster reefs to recover ecosystem services, in K. Cuddington, J.E. Byers, W.G. Wilson, A. Hastings (Eds.), Ecosystem engineers: plants to protists. Elsevier - Academic Press, Amsterdam, pp. 17 (281-298).

Gravestock V, James F, Goulden M. 2014. Solent Native Oyster (Ostrea edulis) Restoration - Literature Review \& Feasibility Study. MacAlister Elliott \& Partners, pp. 77.

Hancock B, Costa D, Ryan K, Turek J, Lazar N. 2006. North Cape Shellfish Restoration Program 2005 Annual Report. Rhode Island Department of Environmental Management National Oceanic and Atmospheric Administration Unit ed States Fish and Wildlife Service, pp. 75.

Hancock B, zu Ermgassen P. 2018. Enhanced Production of Finfish and Large Crustaceans by Bivalve Reefs, in Smaal et al. (Eds.), Goods and Services of Marine Bivalves. Springer, pp. 295-312.

Harding S, Nelson L, Glover T. 2016. Solent Oyster Restoration Project Management Plan. Blue Marine Foundation, pp. 47.

Helmer LD, Farrell P, Hendy I, Harding S, Robertson M, Preston J. 2019. Active management is required to turn the tide for depleted Ostrea edulis stocks from the effects of overfishing, disease and invasive species. PeerJ.
Kamermans P, Brummelhuis EBM, Poelman J, van Gool ACM, Troost K. 2004. Onderzoek naar verbetering broedvangst oesters. RIVO Centrum voor Schelpdierenonderzoek, RIVO rapport C003/04-51.

Kamermans P, Kleissen F, van Duren L, Engelsma M. 2018c. Begrenzing deel Voordelta als niet Bonamia - vrij gebied binnen de Nederlandse Noordzee. Wageningen, C112/18.

Kamermans P, van Duren L, Kleissen F. 2018a. European flat oysters on offshore wind farms: additional locations: opportunities for the development of European flat oyster (Ostrea edulis) populations on planned wind farms and additional locations in the Dutch section of the North Sea. Wageningen Marine Research (University \& Research centre), C053/18, Wageningen, pp. 33.

Kamermans P, Walles B, Kraan M, van Duren L, Kleissen F, van der Have T, Smaal A, Poelman M. 2018b. Offshore wind farms as potential locations for flat Oyster (Ostrea edulis) restoration in the Dutch North Sea. Sustainability 10: 3942.

Keenelyside K, Dudley N, Cairns S, Hall C, Stolton S. 2012. Ecological restoration for protected areas: principles, guidelines and best practices. IUCN.

Kennedy RJ, Roberts D. 1999. A survey of the current status of the flat Oyster Ostrea edulis in Strangford Lough, Northern Ireland, with a view to the restoration of its oyster beds. Biol Environ 99B: 79-88.

Kennedy RJ, Roberts D. 2006. Commercial oyster stocks as a potential source of larvae in the regeneration of Ostrea edulis in Strangford Lough, Northern Ireland. J Mar Biol Assoc UK 86: 153-159.

Kerckhof F, Coolen JWP, Rumes B, Degraer S. 2018. Recent findings of wild European flat oysters Ostrea edulis (Linnaeus, 1758) in Belgian and Dutch offshore waters: new perspectives for offshore oyster reef restoration in the southern North Sea. Belg J Zool 148: $13-24$.

Korringa P. 1941. Experiments and observations on swarming, pelagic life and setting in the European flat oyster, Ostrea edulis L. Archives Néerlandaises de Zoologie. Amsterdam, pp. 249.

Korringa P. 1946. A revival of natural oyster beds. Nature 158: 586587.

Laing I. 2005. Return of the native- is European Oyster (Ostrea edulis) stock restoration feasible? Shellfish News 20.

Laing I, Dunn P, Peeler EJ, Feist SW, Longshaw M. 2014. Epidemiology of Bonamia in the UK, 1982 to 2012. Dis Aquat Org 110: 101-111.

Laing I, Walker P, Areal F. 2005. A feasibility study of native oyster (Ostrea edulis) stock regeneration in the United Kingdom. The Centre for Environment, Fisheries \& Aquaculture Science, pp. 95.

Lallias D, Boudry P, Lapègue S, King JW, Beaumont AR. 2010. Strategies for the retention of high genetic variability in European flat oyster (Ostrea edulis) restoration programmes. Conserv Genet 11: 1899-1910.

Leewis R, de Vries I, Busschbach H. 1997. Lessons from a controversial experiment, in Proceedings of the 30th European Marine Biological Symposium. Southampton, UK.

Lok A, Acarli S. 2006. Preliminary study of settlement of flat oyster spat (Ostrea edulis L.) on oyster and mussel shell collectors. Isr J Aquacult 58: 105-115.

Lotze HK. 2005. Radical changes in the Wadden Sea fauna and flora over the last 2000 years. Helgol Mar Res 59: 71-83.

Lotze HK, Reise K, Worm B, van Beusekom J, Busch M, Ehlers A, Heinrich D, Hoffmann RC, Holm P, Jensen C, Knottnerus OS, Langhanki N, Prummel W, Vollmer M, Wolff WJ. 2005. Human transformations of the Wadden Sea ecosystem through time: a synthesis. Helgol Mar Res 59: 84-95. 
Luckenbach MW, Coen LD, Ross PGJR, Stephen JA. 2005. Oyster reef habitat restoration: relationships between oyster abundance and community development based on two studies in Virginia and South Carolina. J Coastal Res 40: 64-78.

Merk V, Colsoul B, Pogoda B. 2019. Native oyster restoration in the German Bight: Growth and condition of sublittoral Ostrea edulis. $\mathrm{I}$, in preparation.

Metzger JP, Esler K, Krug C, Arias M, Tambosi L, Crouzeilles R, Acosta AL, Brancalion PH, D'Albertas F, Duarte GT. 2017. Best practice for the use of scenarios for restoration planning. Curr Opin Environ Sustain 29: 14-25.

Möbius KA. 1877. Die Austern und die Austernwirtschaft. Berlin, Verlag von Wiegandt, Hepel und Parey. pp. 126.

Naciri-Graven Y, Martin AG, Baud JP, Renault T, Gérard A. 1998. Selecting the flat oyster Ostrea edulis (L.) for survival when infected with the parasite Bonamia ostreae. J Exp Mar Biol Ecol 224: 91-107.

Olsen OT. 1883. The Piscatorial Atlas of the North Sea, English and St. George's Channels - illustrating the fishing ports, boats, gear, species of fish (how, where, and when caught), and other information concerning fish and fisheries. pp. 50.

OSPAR. 2008. OSPAR List of Threatened and/or Declining Species and Habitats. OSPAR Convention for the Protection of the Marine Environment of the North-East Atlantic.

OSPAR. 2009. Background document for Ostrea edulis and Ostrea edulis beds. OSPAR Commission. OSPAR. 482. pp. 22.

OSPAR. 2010. The North-East Atlantic Environment Strategy Strategy of the OSPAR Commission for the Protection of the Marine Environment of the North-East Atlantic 2010-2020.

Pauly D. 1995. Anecdotes and the shifting baseline syndrome of fisheries. Trends Ecol Evol 10: 430.

Peabody B, Griffin K. 2008. Restoring the Olympia Oyster, Ostrea conchaphila. NOOA Fisheries Service 6.

Pogoda B. 2019. Current status of European oyster decline and restoration in Germany. Humanities 8: 9.

Pogoda B, von Nordheim H. 2019. Native oyster and habitat restoration in the German North Sea: defining a conservation framework, in preparation.

Prach K. 2016. Passive Restoration - Allow nature to do the work instead of us. Best Practice in Restoration 10th European Conference on Ecological Restoration. August 22-26, 2016, Freising, Germany.

Reise K. 2005. Coast of change: habitat loss and transformations in the Wadden Sea. Helgol Mar Res 59: 9-21.

Roberts D, Smyth D, Browne L. 2005. Native Oyster (Ostrea edulis) fishery enhancement in Strangford Lough, Northern Ireland. Shellfish News 20.

Rodriguez-Perez A, James M, Donnan DW, Henry TB, Møller LF, Sanderson WG. 2019. Conservation and restoration of a keystone species: understanding the settlement preferences of the European oyster (Ostrea edulis). Mar Pollut Bull 138: 312-321.

Saavedra C. 1997. Low effective sizes in hatchery populations of the European oyster (Ostrea edulis): implications for the management of genetic resources. $J$ Shellfish Res 16: 441-446.

Sas H, Kamermans P, van der Have T, Christianen M, Coolen J, Lengkeek W, Didderen K, Driessen F, Bergsma J, van Dalen P.
2018. Shellfish bed restoration pilots: Voordelta The Netherlands: Annuel report 2017.

Sas H, Kamermans P, van der Have TM. 2016. Shellfish reef restoration project Voordelta, The Netherlands - First interim report.

Shelmerdine RL, Leslie B. 2009. Restocking of the native oyster, Ostrea edulis, in Shetland: habitat identification study. pp. 26.

Smaal A, Kamermans P, Kleissen F, van Duren L, van der Have T. 2017. Flat oysters on offshore wind farms: opportunities for the development of flat oyster populations on existing and planned wind farms in the Dutch section of the North Sea. Wageningen Marine Research, C052/17, Wageningen.

Smaal AC, Kamermans P, van der Have TM, Engelsma M, Sas HJW. 2015. Feasibility of Flat Oyster (Ostrea edulis L.) restoration in the Dutch part of the North Sea. IMARES Wageningen UR, pp. 58.

Smyth D, Roberts D. 2010. The European oyster (Ostrea edulis) and its epibiotic succession. Hydrobiologica 655: 25-36.

Sobolewska H, Beaumont AR. 2005. Genetic variation at microsatellite loci in northern populations of the European flat oyster (Ostrea edulis). J Mar Biol Assoc UK 85: 955-960.

Syvret M, Woolmer A. 2015. Native Oyster, Ostrea edulis - Subtidal Cultivation Handbook.

Thurstan RH, Hawkins JP, Raby L, Roberts CM. 2013. Oyster (Ostrea edulis) extirpation and ecosystem transformation in the Firth of Forth, Scotland. J Nat Conserv 21: 253-261.

University Marine Biological Station Millport. 2007. Conservation of the Native Oyster Ostrea edulis in Scotland.

van Banning P. 1991. Observations on bonamiasis in the stock of the European flat oyster, Ostrea edulis, in the Netherlands, with special reference to the recent developments in Lake Grevelingen. Aquaculture 93: 205-211.

van den Brink AM. 2012. The efficiency of different types of oyster spat collectors for Ostrea edulis. Netherlands, Oysterecover EU FP7 Report. Institute for Marine Resources \& Ecosystem Studies, Wageningen UR, pp. 1-33.

van der Have TM, Kamermans P, van der Zee EM. 2018. Flat oysters in the Eierlandse Gat, Wadden Sea. Bureau Waardenburg, Rapportnr. 17-231, Culemborg.

Vercaemer B, Spence K, Kenchington E, Mallet A, Harding J. 2003. Assessment of genetic diversity of the European oyster (Ostrea edulis) in Nova Scotia using microsatellite markers. Department of Fisheries \& Oceans, Maritimes Region, Science Branch, Bedford, 2453, pp. 30.

Vercaemer B, Spence K, Roach S, MacDonald B, Kenchington E, Mallet A. 2004. Towards a better understanding of European oyster Ostrea edulis breeding: results of the 2003-2004 ACRDP project, Canadian Technical Report of Fisheries and Aquatic Sciences 2563. Canada, Department of Fisheries and Oceans, pp. $1-42$.

Woolmer AP, Syvret M, FitzGerald A. 2011. Restoration of Native Oyster, Ostrea edulis, in South Wales.

zu Ermgassen PSE, Hancock B, DeAngelis B, Greene J, Schuster E, Spalding M, Brumbaugh R. 2016. Setting objectives for oyster habitat restoration using ecosystem services: a manager's guide. TNC, Arlington VA, Arlington VA TNC, pp. 76.

Cite this article as: Pogoda B, Brown J, Hancock B, Preston J, Pouvreau S, Kamermans P, Sanderson W, Nordheim Hv. 2019. The Native Oyster Restoration Alliance (NORA) and the Berlin Oyster Recommendation: bringing back a key ecosystem engineer by developing and supporting best practice in Europe. Aquat. Living Resour. 32: 13 